\title{
THE EFFECT OF TRAINING AND COMPENSATION ON PERFORMANCE EMPLOYEES WITH MOTIVATION AS A MEDIATING VARIABLE
}

\author{
Abdul Hakim ${ }^{1}$ \\ ${ }^{1}$ Faculty of Economics, Universitas Negeri Jakarta \\ Jakarta, Indonesia \\ I Ketut Sudiardhita \\ ${ }^{2}$ Faculty of Economics, Universitas Negeri Jakarta \\ Jakarta, Indonesia \\ ketut.sudhiardhita@unj.ac.id \\ Henry Eryanto ${ }^{3}$ \\ ${ }^{3}$ Faculty of Economics, Universitas Negeri Jakarta \\ Jakarta, Indonesia \\ henryeryanto@unj.ac.id
}

\begin{abstract}
Training and compensation programs are provided by the company to motivate employees and improve employee performance. This study aims to analyze the effect of training and compensation on employee performance using motivation as mediation at PT. Servistama Pacific Sedana. This research uses a quantitative approach with the observation unit of all employees of PT. Sedana Pasifik Servistama and total sampling technique with a total of 110 respondents. The method used is a survey using a questionnaire and descriptive research type explanatory research. This research's data analysis method is the validity test, reliability test, and hypothesis test using SEM (Structural Equation Modeling). The results showed that training and compensation had a positive and significant effect on employee performance. Motivation has a positive and significant effect on employee performance. Motivation can mediate the effect of training on employee performance and motivation to mediate the effect of compensation on employee performance at PT. Servistama Pacific Sedana.
\end{abstract}

Keywords: Training, Compensation, Motivation, Employee Performance 
Today's business competition requires companies to carry out strategies that can grow the company in a better direction. Every company that grows and develops has different risks according to its business field. Business development makes companies need insurance brokerage services to deal with possible risks that arise. The role of insurance brokers is required in providing input, predictions, and calculating potential risks that will be accepted by the company, especially on a particular project.

In line with that, PT. Sedana Pasifik Servistama is a growing insurance brokerage services company. However, today's economic growth has made companies experience ups and downs in achieving their targets directly affected by the ups and downs of organizational performance. One of the factors for the ups and downs of performance is caused by the profit received by the company from 2012 to 2016, which tends to fluctuate. This is due to low employee performance, which results in a significant decrease in organizational performance.

The cause of the decline in profit can be seen from the employee performance data obtained from the Human Resources Department, which is fluctuating and tends to decline. Employee performance data of PT. Sedana Pasifik Servistama shows the absence of employee performance in the last 5 years, which has a performance score of $90 \%$ $100 \%$. The majority of employee performance scores only get in the range of $60 \%-80 \%$, and in 2015 employee performance scores 82\%, so that employee performance is still volatile.

According to Brahmasari \& Suprayetno (2008), organizational performance depends on individual performance. In other words, individual performance will contribute to organizational performance, meaning that the behavior of organizational members both individually and in groups gives strength to organizational performance because their motivation will affect organizational performance. From the performance data indication, it can be concluded that organizational performance has decreased in the last 5 years.

\section{LITERATURE REVIEW}

According to Mangkunegara (2009), performance is the work that can be achieved by a person or group of people in an organization by their respective authorities and responsibilities to achieve organizational goals. Performance results from a person's work 
in carrying out the tasks assigned to him based on skills, experience and sincerity, and time (Hasibuan, 2007).

The first factor is the need for relevant training to make it easier for employees to have professional insurance titles such as CIIB, AAAIK, and AAIK. To make it easier for employees to pass professional examinations, training is needed to support taking exams. Based on the regulation of the Financial Services Authority Number 68 / POJK.05 / 2016 concerning Licensing and Institutional Insurance Brokers, Reinsurance Brokerage Companies, and Insurance Loss Assessment Companies, it is stated that in the market 19 paragraph (1) the company is obliged to organize a capacity building and knowledge development program for its employees. Whereas paragraph (2) states, the development of abilities and knowledge, as referred to in paragraph (1), must be carried out in the form of an education and training program. When employees get a high level of attention and appropriate training, employees will react and feel that their participation in the organization must be reflected in the quality of work and employee interactions with customers (Pansari \& Kumar, 2015).

According to Armstrong (2002), training is a carefully planned, integrated concept designed to generate the understanding needed to improve performance. The training is intended to enhance the assignment of various skills and techniques for specific, detailed, and routine work implementation (Handoko, 2001).

The second factor is the lack of financial compensation and non-financial compensation that employees receive, which triggers employee performance ups and downs. Compensation provided by the company to employees as appropriate remuneration will significantly impact employee satisfaction and increase employee motivation so that better performance is created in achieving organizational goals (Diansyah \& Saepul, 2017).

According to Bernadin (2007), the term compensation is all forms of financial results and tangible benefits received by workers as part of a working relationship. There are financial and non-financial compensation types. Financial compensation is direct or indirect. Direct financial compensation consists of wages received by employees in the form of salaries, wages, bonuses or commissions, indirect financial compensation, or 
benefits consisting of all financial rewards that are not included in direct financial compensation (Ivancevich, 2007).

According to Dhermawan et al. (2012), performance is a function of motivation, skills, and role perceptions. This can be seen from the lack of employee motivation so that the performance given to the company is also low. Motivation is the third factor in decreasing employee performance. Employees who are motivated will do their job because they get satisfaction from their work or want an increase in performance and increase organizational performance (Sankey \& Machin, 2014).

According to Robbins \& Coulter (2005), motivation is the willingness to make high-level efforts to achieve organizational goals, which are conditioned by these efforts' ability to satisfy the needs of several individuals. Motivation is the driving force that results in a member of the organization willing and willing to move his / her ability, energy, and time to carry out various activities that are their responsibility and fulfill their obligations to achieve the goals and objectives of the organization that have been predetermined (Siagian, 2006).

\section{Theoretical Framework}

To clarify this study's direction, which shows the direct effect of training, compensation, and motivation on employee performance, and the indirect effect of training, compensation on employee performance with motivation as an intervening variable (mediation). Then the research framework can be seen in Figure 1.

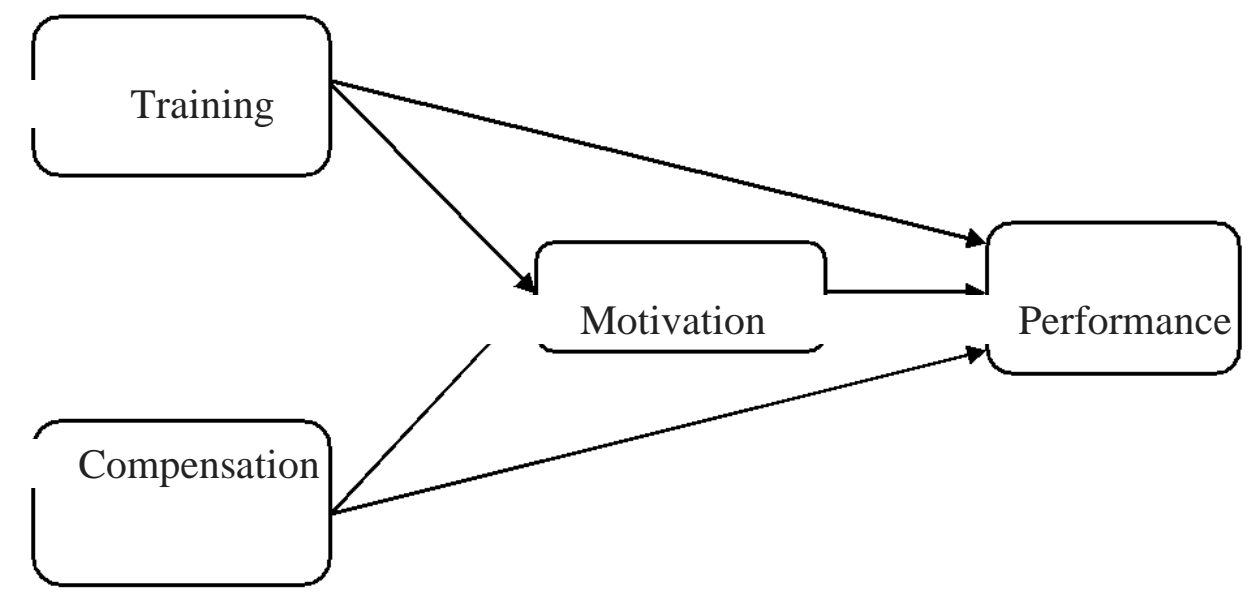

Figure 1. Research Model

\section{RESEARCH METHOD}


The method in this research used a quantitative approach, and the method used is a survey where data is collected from December 2018 to May 2019 with the object of research, namely at PT. Sedana Pasifik Servistama and a population of 110 respondents using sampling techniques, namely saturated sampling or census techniques. Saturated sampling is a sampling technique when all populations are used as samples and are known as a census (Riduwan, 2014).

While the design of this research is grouped into descriptive research to provide an overview of the various characteristics of the proposed variables and their relation to phenomena that occur factually through respondents' perceptions to improve performance with this type of explanatory research because it can describe the relationship of clauses between variables. In this study, the variables used are training, compensation, motivation, and employee performance. Measurement of research variables (constructs) is carried out by deciphering the constructs into operational variables. Each construct can be translated into dimensions then explained by several indicators. Then each indicator is translated in the form of statements so that this will become a research instrument.

Data analysis methods used in this study include descriptive statistical analysis and parametric statistical analysis. Descriptive statistical analysis is used to obtain data that can be used to describe the condition of each research variable, while parametric statistical analysis is used to determine the effect of the independent variable and the dependent variable.

According to Hartono (2004), validity shows how real a test measures what should be measured. The validity test is used to measure whether a questionnaire is valid or not. A questionnaire is said to be valid if the questionnaire's questions can reveal something that will be measured by the questionnaire. To determine the significance value, it is done by comparing the calculated $r$-value with the $r$ table for the degree of freedom $(\mathrm{df})=\mathrm{n}-2$, wherein this case $\mathrm{n}$ is the number of samples.

According to Hartono (2004), reliability is the degree to which a gauge measures stably and consistently. This study uses a one-shot reliability test or one-time measurement. Measurements are made only once and then the results are compared with other questions or measure the correlation between answers to other questions. One-shot measurement was carried out on employees of PT. Sedana Pasifik Servistama, by filling out a 
questionnaire, once tested the validity of this study using the IBM SPSS 23 software. While descriptive statistics are statistics that describe how the relationship between variables regarding the characteristics contained in the available data (Sekaran \& Bougie, 2010).

In analyzing data statistically to answer the proposed hypothesis, the researcher uses Structural Equation Modeling (SEM), a multivariate data analysis technique considering that the use of this model is a combination of path analysis and factorial analysis (Hair et al., 1998). In this study, researchers used AMOS software to assist calculations in research.

\section{RESULT AND DISCUSSION}

\section{Respondent Profile}

Respondents of this study were all employees of PT. Sedana Pasifik Servistama and have attended training programs on insurance, namely training aimed at improving employees' skills and knowledge, especially in the insurance sector. Furthermore, respondents were identified based on gender, age, education, and years of service. This identification needs to be done to determine the general characteristics of the respondent. Descriptive data about the general characteristics of respondents can be seen in Table 1.

Table 1. Respondent Characteristic

\begin{tabular}{|c|c|c|c|}
\hline Category & Characteristic & Frequency & $\begin{array}{c}\text { Percentage } \\
(\%)\end{array}$ \\
\hline & Male & 59 & $54 \%$ \\
\hline \multicolumn{4}{|l|}{ Gender } \\
\hline & Female & 51 & $46 \%$ \\
\hline & - 24 Years & 31 & $28 \%$ \\
\hline & - 34 Years & 14 & $13 \%$ \\
\hline \multicolumn{4}{|l|}{ Age } \\
\hline & - 44 Years & 26 & $24 \%$ \\
\hline & $>45$ Years & 39 & $35 \%$ \\
\hline & SLTA & 16 & $14 \%$ \\
\hline & Diploma & 37 & $34 \%$ \\
\hline \multicolumn{4}{|l|}{ Pendidikan } \\
\hline & \multirow{2}{*}{$\begin{array}{l}\text { S1 } \\
\text { S2 }\end{array}$} & 52 & $47 \%$ \\
\hline & & 5 & $5 \%$ \\
\hline & $0 \quad-4$ Tahun & 42 & $38 \%$ \\
\hline & 5 - 10 Tahun & 28 & $25 \%$ \\
\hline \multicolumn{4}{|l|}{ Work length } \\
\hline & - 15 Tahun & 25 & $23 \%$ \\
\hline
\end{tabular}




\section{$>15$ Tahun \\ 15 \\ Source: Results of Data Processing}

$14 \%$

\section{CFA Test Results (Confirmatory Factor Analysis)}

CFA analysis (confirmatory factor analysis) was used to test the indicators and dimensions of the variables. This analysis is carried out on each variable consisting of training, compensation, motivation, and employee performance with details of the results of the calculation of goodness of fit, an indication of each variable that all constructs used have met the criteria for the goodness of fit and thus can be used in the next model. For the results of the CFA (confirmatory factor analysis), all variables can be seen in Table 2 below:

Table 2. CFA Results

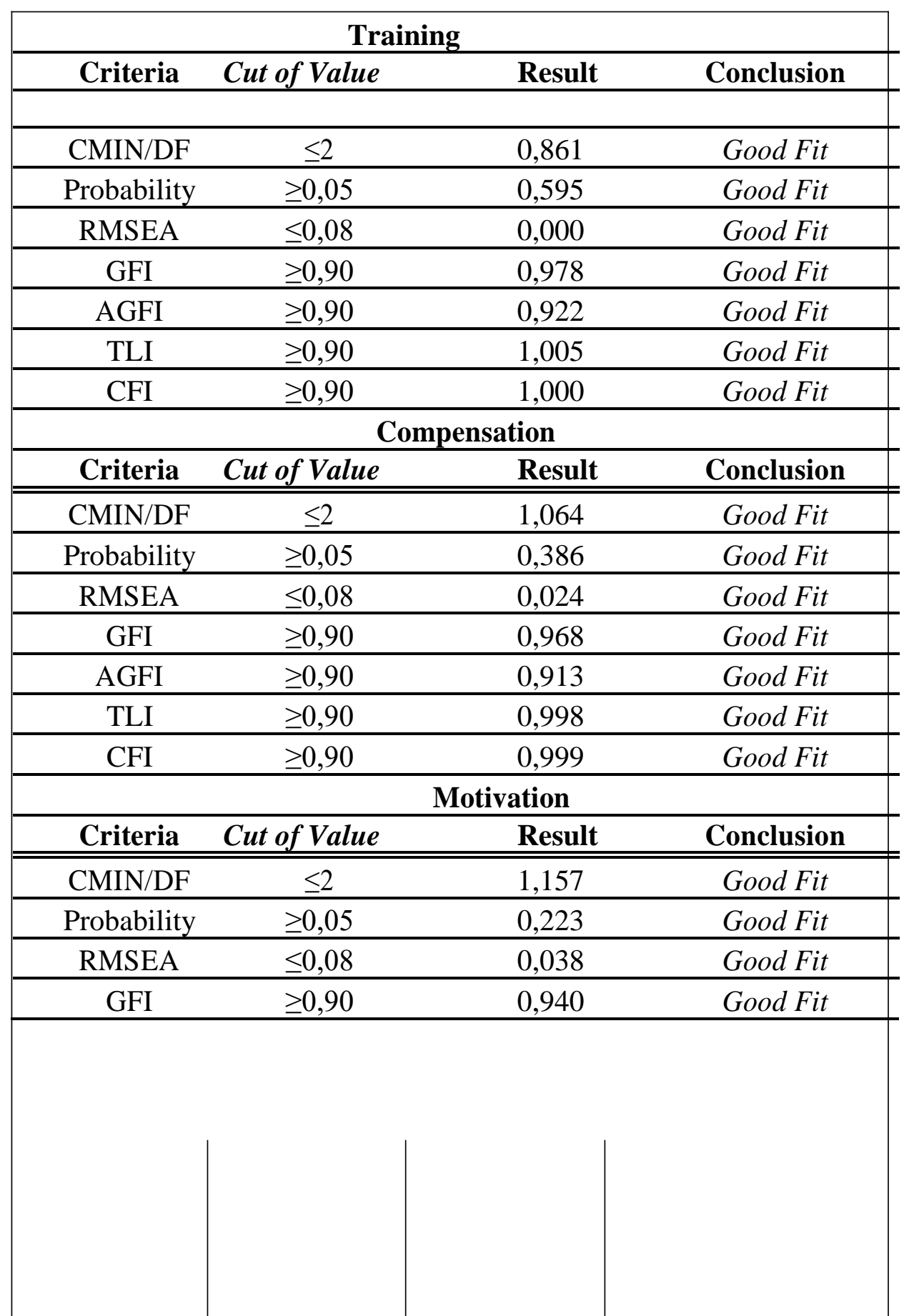




\begin{tabular}{cccc}
\hline AGFI & $\geq 0,90$ & 0,872 & Margin Fit \\
\hline TLI & $\geq 0,90$ & 0,993 & Good Fit \\
\hline CFI & $\geq 0,90$ & 0,996 & Good Fit \\
\hline & & Performance & \\
\hline Criteria & Cut of Value & Result & Conclusion \\
\hline CMIN/DF & $\leq 2$ & 1,080 & Good Fit \\
\hline Probability & $\geq 0,05$ & 0,260 & Good Fit \\
\hline RMSEA & $\leq 0,08$ & 0,027 & Good Fit \\
\hline GFI & $\geq 0,90$ & 0,890 & Margin Fit \\
\hline AGFI & $\geq 0,90$ & 0,842 & Margin Fit \\
\hline TLI & $\geq 0,90$ & 0,990 & Good Fit \\
\hline CFI & $\geq 0,90$ & 0,992 & Good Fit
\end{tabular}

Source: Results of Data Processing

Based on the results of the data processing above, it can be seen that the test results (confirmatory factor analysis) show that the majority of the results are a good fit, this shows that the variables and dimensions used in this study have met the criteria of goodness of fit, thus all variables can be used. in later models.

The full model measurement results can be seen in Table 3 below:

Table 3. The goodness of Fit Result

\begin{tabular}{|c|c|c|c|}
\hline & & Result & \multirow[b]{3}{*}{ Conclusion } \\
\hline \multirow[b]{2}{*}{ Criteria } & Cut of Value & \multirow[b]{2}{*}{ Goodness } & \\
\hline & & & \\
\hline & & of Fit & \\
\hline $\mathrm{X} 2-\mathrm{Chi}-$ & & & \\
\hline \multirow[t]{2}{*}{ Square } & Small Expected & 2026,119 & Poor Fit \\
\hline & RMSEA $\leq 0,08$ & & \\
\hline \multirow[t]{3}{*}{ RMSEA } & $0,08 \leq$ RMSEA $<0,10$ & 0,092 & Pood Fit \\
\hline & RMSEA $\geq 0,10$ & & \\
\hline & $\mathrm{GFI} \geq 0,09$ & & \\
\hline \multirow[t]{3}{*}{ GFI } & $0,08 \leq \mathrm{GFI}<0,09$ & 0,619 & Poor Fit \\
\hline & $\mathrm{GFI} \leq 0,08$ & & \\
\hline & $\mathrm{AGFI} \geq 0,90$ & & \\
\hline AGFI & $0,80 \leq \mathrm{AGFI}<0,90$ & 0,577 & Poor Fit \\
\hline
\end{tabular}




\begin{tabular}{|c|c|c|c|}
\hline CMIN/DF & $\mathrm{CMIN} / \mathrm{DF} \leq 2$ & 1,915 & Good Fit \\
\hline & $\mathrm{TLI} \geq 0,90$ & & \\
\hline \multirow[t]{3}{*}{ TLI } & $0,80 \leq \mathrm{TLI}<0,90$ & 0,803 & Marginal Fit \\
\hline & $\mathrm{TLI} \leq 0,80$ & & \\
\hline & $\mathrm{CFI} \geq 0,90$ & & \\
\hline \multirow[t]{2}{*}{$\mathrm{CFI}$} & $0,80 \leq \mathrm{CFI}<0,90$ & 0,815 & Marginal Fit \\
\hline & $\mathrm{CFI} \leq 0,80$ & & \\
\hline \multirow[t]{2}{*}{ PGFI } & $\mathrm{PGFI} \geq 0,50$ & 0,557 & Good Fit \\
\hline & IFI $\geq 0,90$ & & \\
\hline \multicolumn{4}{|l|}{ IFI } \\
\hline & $0,80 \leq \mathrm{IFI}<0,90$ & 0,917 & Good Fit \\
\hline & $\mathrm{IFI} \leq 0,80$ & & \\
\hline
\end{tabular}

Source: Results of Data Processing

Based on Table 3 above, 3 GOF sizes show good fit, 2 sizes that indicate marginal fit, and 4 sizes that indicate poor fit. Therefore it can be concluded that the overall fit of the model in this study is poor. Based on these results it can be concluded that the measurement model, in general, has not met the suitability requirements and it was decided to carry out a fit model in the estimate result interpretation step. Following are the results of the full model estimate based on IBM AMOS:

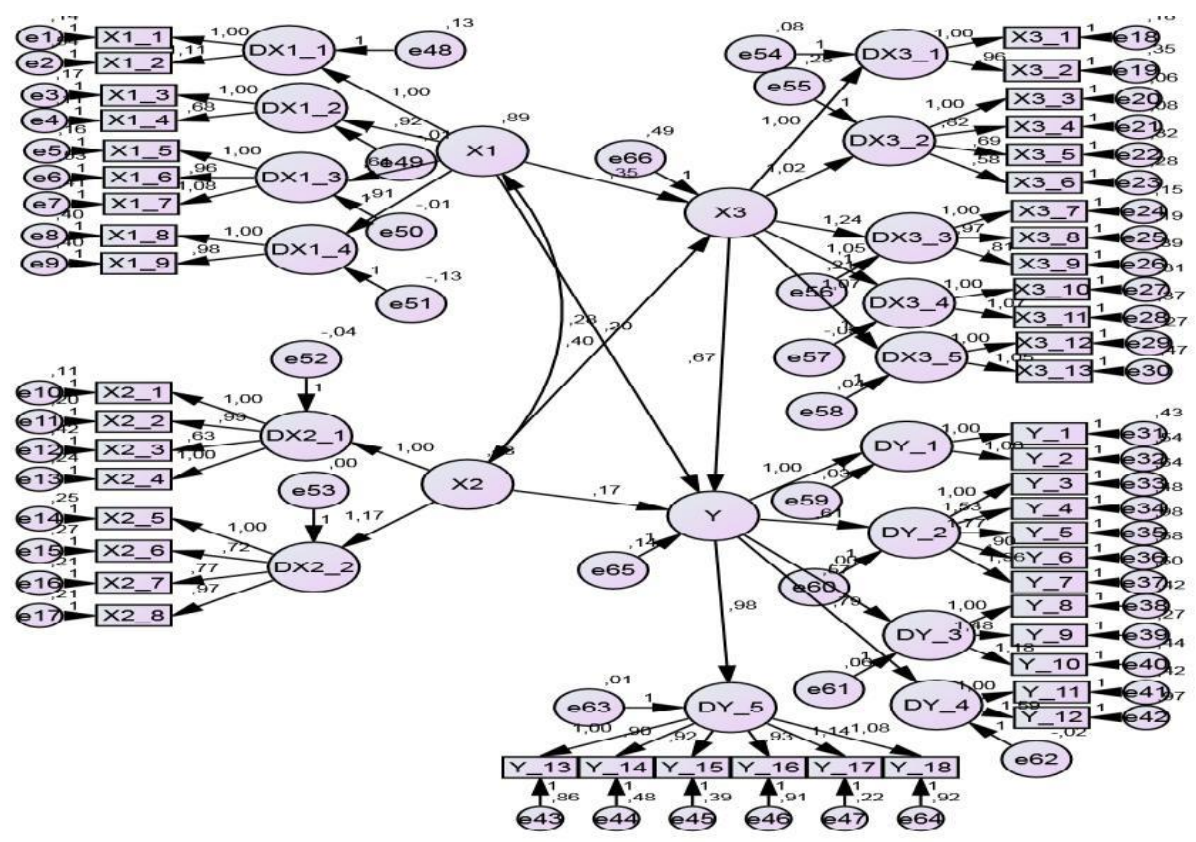


Figure 3. Full-size model image

The results of the fit model size can be seen in Table 4 below:

Table 4. The goodness of Fit Result

\begin{tabular}{|c|c|c|c|}
\hline & & Result & \multirow[b]{3}{*}{ Conclusion } \\
\hline \multirow[b]{2}{*}{ Criteria } & Cut of Value & \multirow[b]{2}{*}{ Goodness } & \\
\hline & & & \\
\hline & & \multicolumn{2}{|l|}{ of Fit } \\
\hline $\mathrm{X} 2-C h i$ & & & \\
\hline Square & Diharapkan kecil & 512,849 & Good Fit \\
\hline \multicolumn{4}{|c|}{ RMSEA $\leq 0,08$} \\
\hline RMSEA & $0,08 \leq \mathrm{RMSEA}<0,10$ & 0,000 & Good Fit \\
\hline \multicolumn{4}{|c|}{ RMSEA $\geq 0,10$} \\
\hline \multicolumn{4}{|c|}{$\mathrm{GFI} \geq 0,09$} \\
\hline GFI & $0,08 \leq \mathrm{GFI}<0,09$ & 0,822 & Marginal Fit \\
\hline \multicolumn{4}{|c|}{$\mathrm{GFI} \leq 0,08$} \\
\hline \multicolumn{4}{|c|}{$\mathrm{AGFI} \geq 0,90$} \\
\hline AGFI & $0,80 \leq \mathrm{AGFI}<0,90$ & 0,778 & Poor Fit \\
\hline \multicolumn{4}{|c|}{$\mathrm{AGFI} \leq 0,80$} \\
\hline CMIN/DF & $\mathrm{CMIN} / \mathrm{DF} \leq 2$ & 0,860 & Good Fit \\
\hline \multirow{3}{*}{ TLI } & $\mathrm{TLI} \geq 0,90$ & & \\
\hline & \multirow{2}{*}{$\begin{array}{c}0,80 \leq \mathrm{TLI}<0,90 \\
\text { TLI } \leq 0,80\end{array}$} & 1,026 & Good Fit \\
\hline & & & \\
\hline & $\mathrm{CFI} \geq 0,90$ & & \\
\hline CFI & $0,80 \leq \mathrm{CFI}<0,90$ & 1,000 & Good Fit \\
\hline PGFI & $\mathrm{PGFI} \geq 0,50$ & 0,661 & Good Fit \\
\hline & $\begin{array}{c}\text { IFI } \geq 0,90 \\
0,80 \leq \mathrm{IFI}<0,90\end{array}$ & & \\
\hline IFI & IFI $\leq 0,80$ & 1,026 & Good Fit \\
\hline
\end{tabular}

Source: Results of Data Processing

Based on Table 4 above, 7 GOF sizes show good fit, 1 size that shows marginal fit, and 1 size that shows poor fit. Therefore it can be concluded that the overall fit of the model in this study is a good fit. Based on these results, it can be concluded that the measurement 
model generally meets the suitability requirements and it is decided to proceed to the estimate result interpretation step. Following are the results of estimating fit models based on IBM AMOS:

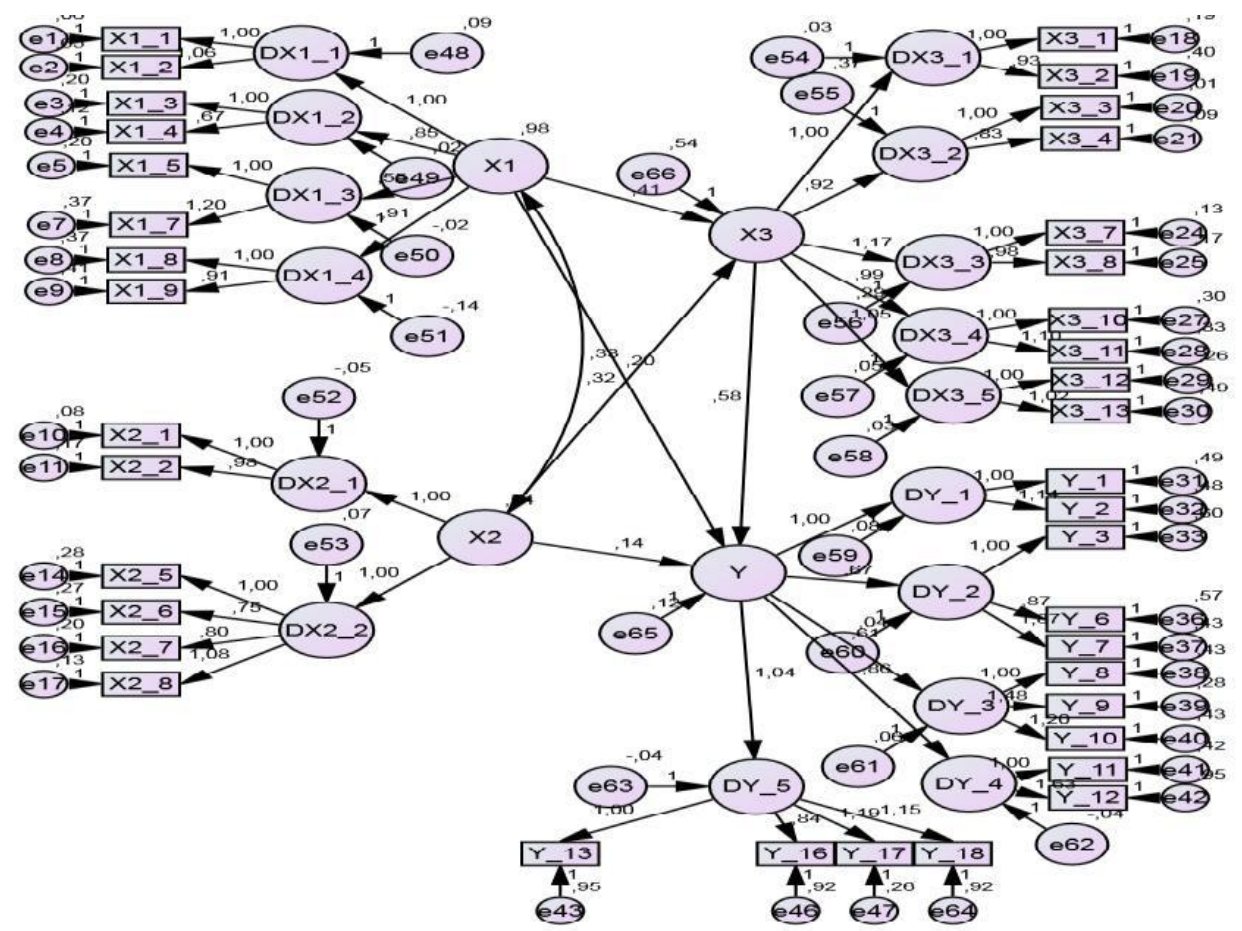

Figure 4. Figure fit model size

\section{Hypothesis Results and Causal Relationships}

The following are the results of hypothesis testing after most of the goodness of fit criteria are met, so that the coefficient of each factor is more reliable as seen in the causality test in table 5 below:

\begin{tabular}{|c|c|c|c|c|c|}
\hline Hypotheses & Relationship & Estimate & C.R. & $\begin{array}{r}P- \\
\text { Value }\end{array}$ & Information \\
\hline $\mathrm{H} 1$ & Training $\rightarrow$ Motivation & 0,408 & 4,927 & 0,000 & Accepted \\
\hline $\mathrm{H} 2$ & $\begin{array}{l}\text { Compensation } \\
\text { Motivation }\end{array}$ & 0,322 & 2,882 & 0,004 & Accepted \\
\hline $\mathrm{H} 3$ & $\begin{array}{l}\text { Training } \rightarrow \text { Employee } \\
\text { Performance }\end{array}$ & 0,581 & 7,634 & 0,000 & Accepted \\
\hline $\mathrm{H} 4$ & $\begin{array}{l}\text { Compensation } \rightarrow \\
\text { Employee Performance }\end{array}$ & 0,136 & 2,352 & 0,019 & Accepted \\
\hline $\mathrm{H} 5$ & $\begin{array}{l}\text { Motivation } \rightarrow \text { Employee } \\
\text { Performance }\end{array}$ & 0,201 & 3,886 & 0,000 & Accepted \\
\hline & $\begin{array}{l}\text { Training } \rightarrow \text { Employee } \\
\text { Performance }\end{array}$ & & & & \\
\hline H6 & & 0,980 & 0,149 & 6,562 & Accepted \\
\hline
\end{tabular}




\begin{tabular}{|c|c|c|c|c|c|c|}
\hline & $\begin{array}{c}\text { Mediated } \\
\text { Motivation }\end{array}$ & by & & & & \\
\hline & $\begin{array}{c}\text { Compensation } \\
\text { Work perfomance }\end{array}$ & $\rightarrow$ & & & & \\
\hline $\mathrm{H} 7$ & Mediated & by & 0,538 & 0,081 & 6,645 & \\
\hline
\end{tabular}

Source: Results of Data Processing

From Table 5 above, it can be seen that all hypotheses from the first hypothesis (H1) to the seventh hypothesis (H7) are accepted or can be said to be positive and significant, this is because the estimated value is greater than the P-value for the first hypothesis ( H1) to the fifth hypothesis (H5). The sixth hypothesis (H6) and the seventh hypothesis (H7) are positive and significant because the C.R value in this study is greater than 1.96. This shows that there is a positive and significant effect on all hypotheses in this study.

This study's results reinforce the results of previous research conducted by Rahmah \& Makian (2016) that there is a positive and significant effect of training on motivation. Also, research conducted by Agusta \& Madiono (2013) states that training has a positive and significant effect on motivation.

The results of this study support the opinion of Murty \& Hudiwinarsih (2012), which shows the conclusion that there is a positive and significant effect of compensation on motivation. Also, research conducted by Sihar \& Khuzaini (2015) states that compensation has a positive and significant effect on motivation.

This research is also in line with a study conducted by Nuwati (2012), which concludes that there is a positive and significant effect of training on employee performance. Also, research conducted by Imanuel \& Khuzaini (2015) states that training has a positive and significant effect on employee performance.

This study's results reinforce previous research conducted by Dhermawan \& Sudibya (2012), which states that compensation has a positive and significant effect on employee performance. Also, research conducted by Nuwati (2012) shows the conclusion that there is a positive and significant effect of compensation on employee performance.

This research is also in line with the empirical study conducted by Suwati (2013), which states that there is a positive and significant influence of motivation on employee 
performance. Also, research conducted by Andayani \& Makian (2016) states that there is a positive and significant influence on motivation on employee performance.

On the other hand, this study supports the results of research conducted by Diansyah \& Saepul (2012), which proves that motivation has a positive mediating role in the effect of training on employee performance. This study's results are supported by research conducted by Ernur \& Machasin (2017), proving that motivation has a positive mediating role in the effect of compensation on employee performance.

\section{CONCLUSION}

\section{Conclusion}

Based on the results of research and analysis, the researcher can make the following conclusions:

1. Training has a positive and significant effect on motivation. If the training provided to employees is getting better, the employee's motivation will increase.

Vice versa, if the training provided is irrelevant, the employee's motivation will also not increase.

2. Compensation has a positive and significant effect on motivation. If the compensation given to employees is getting better, the employee's motivation will increase. Likewise, if the compensation provided does not increase, employee motivation will not increase either.

3. Training has a positive and significant effect on employee performance. If the training provided is relevant to the job, the employee's performance will increase. Vice versa, if the training provided is not relevant to the job, the employee's performance will not increase either.

4. Compensation has a positive and significant effect on employee performance. If the compensation given increases, the employee's performance will increase. Vice versa, if the compensation provided does not increase, the employee's performance will not increase either.

5. Motivation has a positive and significant effect on employee performance. If the employee's motivation is high, then the employee's performance will increase. Vice versa, if the employee's motivation is low, the employee's performance will not increase either. 
6. Motivation has a positive and significant mediating role in the effect of training on employee performance. If employees receive relevant training, they will be motivated to work and directly impact employee performance.

7. Motivation has a positive and significant mediating role in the effect of compensation on employee performance. If employees' compensation increases, then employees will be motivated to work and have a direct impact on improving employee performance.

\section{Suggestion}

Employee performance is influenced by training, compensation, and motivation. Several aspects need to be considered by companies to improve employee performance. The training provided to employees must be relevant and provide work motivation to employees to automatically improve employee performance. The company must also provide appropriate compensation to create employee motivation to achieve company goals by increasing employee performance. Companies must also motivate employees, which has a direct impact on improving employee performance.

Researchers admit that there are limitations from various aspects of this study. Further research is suggested to examine other factors related to performance such as leadership, communication, and career development. The number of respondents also needs to be added to generalize the research results better.

\section{References}

Agusta, L., \& Sutanto, E. M. (2013). Pengaruh Pelatihan dan Motivasi Kerja Terhadap Kinerja Karyawan CV Haragon Surabaya. AGORA, 1(3).

Andayani, Nur Rahmah \& Makian, P. (2016). Pengaruh Pelatihan Kerja dan Motivasi Kerja terhadap Kinerja Karyawan Bagian PT. PCI Elektronik International (Studi pada Karyawan PT PCI Elektronik International). Jurnal Akuntansi, Ekonomi Dan Manajemen, 4(1), 41-46.

Armstrong, Michael. (2002). Manajemen Sumber Daya Manusia. Jakarta: PT. Elex Media Komputindo.

Bernadin, J. (2007). Human ResourceManagement.New York: McGraw-Hill Irwin. 
Dhermawan, A. A., Sudibya, I. G. A., \& Utama, I. W. M. (2012). Pengaruh Motivasi, Lingkungan Kerja, Kompetensi, dan Kompensasi terhadap Kepuasan Kerja dan Kinerja Pegawai di Lingkungan Kantor Dinas Pekerjaan Umum Provinsi Bali. Jurnal Manajemen, Strategi Bisnis, Dan Kewirausahaan, 6(2), 173-184.

Diansyah \& Saepul, T. (2017). Pengaruh Pelatihan dan Kompensasi terhadap Kinerja Karyawan dengan Motivasi sebagai Variabel Intervening pada Mikro Laju Cluster Jakarta 2 PT. Bank Cimb Niaga, Tbk. Jurnal Online Internasional \& Nasional Universitas 17 Agustus 1945 Jakarta, 20(1).

Ernur, M. M. H., Machasin., \& Marhadi. (2014). Pengaruh Pelatihan, Kompensasi dan Pengembangan Karir terhadap Kinerja Karyawan Bagian Penjualan dengan Motivasi sebagai Variabel Mediasi Pada PT. Gulang Medica Indah Pekanbaru. JOM FEKON, 1(2).

Handoko, T. Hani. (2001). Manajemen Personalia dan Sumber Daya Manusia. Yogyakarta: BPFE.

Hartono M, J. (2004). Metodologi Penelitian Bisnis Salah Kaprah dan PengalamanPengalaman (6th ed.). Yogyakarta: BPFE Yogyakarta.

Hasibuan, Malayu S. P. (2007). Manajemen: Dasar, Pengertian dan Masalah. Jakarta: Bumi Aksara, Cetakan Keenam, Edisi Revisi.

Ida Ayu Brahmasari, \& Agus Suprayetno. (2008). Pengaruh Motivasi Kerja, Kepemimpinan dan Budaya Organisasi Terhadap Kepuasan Kerja Karyawan serta Dampaknya pada Kinerja Perusahaan (Studi kasus pada PT. Pei Hai International Wiratama Indonesia). Jurnal Manajemen Dan Kewirausahaan, 10(2), 124-135. https://doi.org/10.9744/jmk.10.2.pp. 124-135.

Ivancevich, John M. (2007). Human Resource Management. New York: McGraw Hill. Mangkunegara, Anwar Prabu. (2009). Manajemen Sumber Daya Manusia Perusahaan. Bandung: PT. Remaja Rosdakarya.

Murty, W. A., \& Hudiwinarsih, G. (2012). Pengaruh Kompensasi, Motivasi Dan Komitmen Organisasional Terhadap Kinerja Karyawan Bagian Akuntansi (Studi Kasus Pada Perusahaan Manufaktur Di Surabaya). The Indonesian Accounting Review, 2(2), 215-228. 
Nurwati. (2012). Pengaruh Pelatihan, Kompensasi, dan Komitmen terhadap Kinerja karyawan (Studi Kasus Pada Karyawan Rumah Sakit Umum Daerah Se-Provinsi Sulasewi Tenggara). Jurnal Manajemen dan Kewirausahaan, 4(2), 15-27.

Pansari, A., \& Kumar, V. (2015). Measuring the Benefits of Employee Engagement Measuring the Benefits of Employee Engagement, 56(4).

Ridwan. (2014). Metode dan Teknik Menyusun Tesis. Bandung: Alfabeta.

Robbins, Stephen P \& Coulter, Mary. (2005). Manajemen. Jakarta: PT. Indeks Kelompok Gramedia.

Sankey, K. S., \& Machin, M. A. (2014). Employee participation in non mandatory professional development - the role of core proactive motivation processes. International Journal of Training and Development, 18(4), 241-255.

Sekaran, U., \& Bougie, R. (2010). Research Methods for Business: A Skill Building Approach (5, illustr ed.). John Wiley \& Sons.

Siagian, P. Sondang. (2006). Manajemen Sumber Daya Manusia. Jakarta: Bumi Aksara.

Siagian, S.S.I. \& Khuzaini. (2015). Pengaruh Pelatihan, Kepuasan Kompensasi, Motivasi dan Disiplin Kerja terhadap Kinerja Karyawan. Jurnal Ilmu dan Riset Manajemen, 4(9).

Suwati, Y. (2013). Pengaruh Kompensasi dan Motivasi Kerja terhadap Kinerja Karyawan pada PT. Tunas Hijau Samarinda. E-Journal Ilmu Administrasi Bisnis, 1(1), 41-55. 